\title{
Evolution of Resistance to Insecticide in Disease Vectors
}

\author{
P. Labbé ${ }^{1}$, J.-P. David ${ }^{2}$, H. Alout ${ }^{1,3}$, P. Milesi ${ }^{1}$, L. Djogbénou ${ }^{4}$, N. Pasteur ${ }^{1}$, \\ M. Weill ${ }^{1}$
}

${ }^{1}$ Institut des Sciences de l'Evolution de Montpellier (UMR 5554, CNRS-UM-IRD-EPHE), Université de Montpellier, Montpellier, France; ${ }^{2}$ Laboratoire d'Ecologie Alpine (UMR 5553 CNRS-UGA), Université Grenoble-Alpes, Grenoble, France; ${ }^{3}$ Colorado State University, Fort Collins, CO, United States; ${ }^{4}$ Université d'Abomey Calavi, Cotonou, Benin

\section{Introduction}

The control of vector-borne diseases represents one of the greatest global public health challenges of the 21 st century. They contribute substantially to the global burden of infectious diseases $(\sim 17 \%)$ and their prevalence tends to increase (World Health Organization ${ }^{1}$ ). Human population growth in many areas has led to extensive deforestation, irrigation, and urbanization, and these environmental modifications have created conditions that favor the proliferation of many arthropod vectors, such as mosquitoes, ticks, flies, and so on. Primarily in developing countries, 3.2 billion people are now at risk for contracting many new or reemerging diseases. ${ }^{2}$

Mosquitoes are probably the most common vectors of infectious diseases (review in Ref. 3); 3500 species are found throughout the World and, in almost all species, the females find the proteins they need for developing eggs through blood-feeding on vertebrates. This makes mosquitoes particularly prone to transfer viruses and other parasites between humans and animals hosts. They are vectors of malaria and arboviruses (dengue, yellow fever, zika, Japanese encephalitis, west nile, and chikungunya). Other major vector-borne diseases (sleeping sickness, leishmaniasis, onchocerciasis, plague, Bartonellosis, rickettsioses, Lyme disease, ehrlichiosis, babesiosis, anaplasmosis, trypanosomiasis, Chagas disease, and several viral diseases) are transmitted by nonmosquito arthropods (tsetse flies (Glossina sp.), sand flies (Phlebotominae), black flies (Simulidae), houseflies, fleas, lice, cockroaches, and Triatomine bugs).

Some tropical vector-borne diseases have been observed in developed countries (e.g., Chikungunya or West Nile virus in Europe and USA). If climate (temperature, rainfall, and humidity) does influence disease transmission, expansion of disease range is mostly due to human factors, such as forest clearing, increased travel, transport, and economical activities (e.g., the geographic distribution of Aedes albopictus has considerably increased through worldwide commerce of used tires and because of its capacity of diapausing and the resistance of its eggs to desiccation ${ }^{4}$ ). Overall, it seems that the main determinants of vector-borne diseases' prevalence are socioeconomic (see Refs. 5-7). Unfortunately, the burden that vector-borne diseases impose directly impairs the 
public health and socioeconomic development of many of the poor areas. Controlling these diseases is thus a necessity. This ideally entails active case-detection and treatment of human infections (vaccines, antiparasitic drugs). However, few vaccines are currently available (e.g., for yellow fever, Japanese encephalitis) and many pathogens, such as Plasmodium, are now resistant to antiparasitic drugs. Moreover, populations from endemic countries struggle to get access to them, notably due to economic impediments. Thus in many instances, the control of vectors is the only affordable measure.

The first documented attempts to control malaria by limiting the densities of vectors go back to the Roman times: in an attempt to control the "Roman fever" (the name of malaria at that time), Julius Caesar himself had the Codetan swamp around Rome drained and planted with trees (Varro about $40 \mathrm{BC}^{8}$ ). While such environmental modifications aiming at reducing the number of breeding sites have shown great success, today the most common and affordable way of fighting the major disease vectors is the use of insecticides. ${ }^{9-11}$ Many scientific investigations and reports show that the use of synthetic insecticides can dramatically reduce the risk of insect-borne diseases. Insecticides, combined with extensive use of drugs, have rapidly led to the eradication of many diseases (e.g., malaria) from most nontropical areas of the world, but in spite of initial successes, eradication has proven more elusive in the tropics. ${ }^{12}$ However, mechanisms allowing survival to insecticide exposures have been selected in many species of arthropod vectors. Resistance to all classes of synthetic insecticides is now widespread among pests of public health importance, and it is considered to be the most important impediment in the successful control of vector-borne diseases.

\section{Insecticide Resistance: Definition and History}

Insecticide resistance in pest populations affects both economy and public health at a worldwide scale: it decreases crop yields (and thus profitability), induces the need to increase the quantity of insecticide and to develop new insecticides (thereby having a strong impact on costs and on the environment), and finally it is responsible for higher incidence of human or animal diseases. ${ }^{13,14}$ This general society problem, however, provides evolutionary biologists with a unique contemporary model, ideal for studying how new adaptations evolve by natural selection. The selecting agent is known (insecticides), evolution is recent and rapid (few years after insecticide selection), and the biological and genetic mechanisms are often known (see Part 3). This explains why it has been the subject of such a large body of work over the years.

Resistance is defined as a heritable decrease of the susceptibility to an insecticide. ${ }^{15}$ Three categories of resistance can be distinguished: behavioral (avoidance of contact with insecticide), physiological (e.g., increased cuticle thickness), and biochemical (enhanced insecticide detoxification and sequestration and/or decreased insecticide target sensitivity). Few examples of behavioral (e.g., Anopheles gambiae on Bioko Island and Senegal ${ }^{16,17}$ or Anopheles funestus in Benin and Tanzania ${ }^{18-20}$ ) and physiological resistances have been reported; whether they are heritable remains debated, and it is difficult to assess the level of protection they provide. Biochemical resistances 
typically result in relatively high level of protection and are genetically determined. Resistant individuals carry one or several genetic mutations that prevent insecticide disruption of the target functioning. As a result, the frequency of resistance gene(s)/allele(s) increases in the population over time. Insecticide resistance is confirmed by toxicological tests (bioassays) establishing resistance ratio (or RR corresponding to the number by which an insecticide dose must be multiplied in order to obtain the same mortality in resistant than in susceptible insects). It can be investigated at many levels, from the molecular characterization of genes/alleles conferring resistance and their biochemical products, to the effect of these genes on the fitness (i.e., mean reproductive success) of the individuals carrying resistance alleles, to the dynamics and evolution of these resistance alleles in natural vector populations and their effect on disease control.

The first recorded attempt of insect pest control, the application of tobacco juice against sheep scabs, is found in the literature of the 18 th century. ${ }^{21}$ The first case of resistance was reported in 1908, in a population of San Jose scale (Aspidiotus perniciosus) resistant to lime sulfur. ${ }^{22}$ A century later (2007), 553 arthropod species were reported as resistant to at least one insecticide, among many disease vectors. More than 100 mosquito species are resistant to at least one insecticide (including 56 Anopheline species, 39 Culicine species); Culex pipiens pipiens and Anopheles albimanus are resistant to more than 30 different compounds. ${ }^{14}$

\subsection{Synthetic Insecticides}

Originally, only inorganic insecticides (such as lime sulfur) and natural products were available, for example, flower-extracted pyrethrum for malaria control in the 1930s. Today, four classes of organic (synthetic) insecticides are essentially used: the organochlorines (OCs), the organophosphates (OPs), the carbamates (CXs), and the pyrethroids (PYRs), with, respectively, 4429, 1375, 30, and 414 metric tonnes of active ingredient used annually for global vector control from 2000 to $2009 .^{23}$

The first synthetic insecticides, introduced during World War II for malaria control, belonged to the OC class. The first one was the dichlorodiphenyltrichloroethane or DDT (introduced in 1943), which targets the voltage-gated sodium channels (Na-channels); another was the cyclodiene (CD) dieldrin, which targets the $\gamma$-aminobutyric acid (GABA) receptor; both targets being essential in the insect nervous system (see Part 3). In addition to their public health applications, enormous tonnages of DDT and dieldrin were used worldwide in agriculture. It was at first a great success with large WHO-led campaigns leading to reduction of morbidity and mortality from malaria in many endemic regions after World War II. Widely acclaimed, DDT and dieldrin rapidly selected resistance in insect vectors. In An. gambiae, resistance to DDT was first noted 11 years after its introduction, ${ }^{24}$ while a population from northern Nigeria was reported resistant to dieldrin soon after. ${ }^{25}$ DDT resistance has now been reported in mosquitoes (Aedes sp., Anopheles sp., and Culex sp.), houseflies, sand flies, body lice, and head lice, while resistance to dieldrin ( $60 \%$ of reported cases of resistance before 1990) has been detected in more than 277 arthropods, including mosquitoes (Aedes sp., Anopheles sp., and Culex sp.), fleas, ticks, biting flies, bedbugs, cockroaches, and human lice. $^{1,9,10,26,27}$ 
An important issue against these insecticides was their environmental impact. Rachel Carson's book "Silent Spring" ${ }^{28}$ was a seminal work publicizing and politicizing the toxic effects of the accumulation of DDT and its metabolites in the food chain. In vertebrates, DDT can interfere with reproduction, and in humans it can have neurologic, carcinogenic, and reproductive effects, although the evidences remain debated. These insecticides are also extremely stable in the environment, contaminating groundwater and remaining in soil long after their use. In the 1970s, the Persistent Organic Pollution Treaty led to total banning of dieldrin and to the banning of DDT for all uses except malaria control when this disease is very frequent and there is no alternative. DDT use rapidly declined in the 1970s (it is no longer used in Latin America), ${ }^{29}$ but it gained new advocates due to the development of resistance to the alternative insecticides, and to its low cost. ${ }^{1,29-32}$ Consequently, its use quadrupled between 2007 and 2009. ${ }^{23}$

From the late 1970s, OCs were replaced by the PYRs class of vector control, and these became widely used in agriculture and public health, and more particularly against malaria vector. They are today by far the most-used insecticides, with $81 \%$ of the World spray coverage. ${ }^{23}$ As DDT, these insecticides target the Na-channels (i.e., neurotoxic effect). Their rapid popularity comes from their very low toxicity to human, their rapid knock-down (KD) effect associated with an excitorepellancy effect. PYR-based indoor residual spraying (IRS) and insecticide-treated nets and curtains (ITNs) are currently advocated as standard malaria vector control strategies. ${ }^{1}$

PYR resistance was reported in 1993, in An. gambiae populations from Côte d'Ivoire ${ }^{33}$ and later in C. pipiens quinquefasciatus also in West Africa. ${ }^{34}$ Resistance is now widespread in mosquitoes (Aedes sp., Anopheles sp., and Culex sp. (see Ref. 35 for a review)), body and head lice, ticks (e.g., Boophilus microplus), and fleas. ${ }^{1,9,10}$ As PYR resistance developed, many control programs attempted to revert to DDT for disease control. However, these insecticides share a common target site, and there is cross-resistance to both insecticide classes in many locations. ${ }^{30,32}$

Finally, two other classes of synthetic insecticides are used at a large scale worldwide: the OPs and the CXs, which were first used in the 1940s and the 1950s, respectively. ${ }^{1,15}$ OPs and CXs target the synaptic acetylcholinesterase (AChE), an essential enzyme in the nervous system. They are usually used as larvicids (although some are now considered for ITN impregnation and IRS as an alternative to $\mathrm{PYR}^{36}$ ), and are particularly well suited for species with delimited breeding sites. However, they have a short half-life, and two to three rounds of IRS are needed per year. This, combined in some instances with their high price, can make these insecticides too costly for most malaria control programs, despite fewer reports of resistance. ${ }^{32}$ Early resistance to these insecticides has been detected shortly after their first application: for example, first OP treatments in the Montpellier area (southern France) started in 1969, the first resistance being detected only 3 years later. ${ }^{37}$ Resistance has now been recorded in mosquitoes (Aedes sp., Anopheles sp., and Culex sp.), biting flies (e.g., Simulium damnosum, vector of onchocerciasis), sand flies, houseflies, and fleas (reviews in Refs. 1,10,26,27).

During 2006-2008, few new insecticides were described: neonicotinoids, phthalic acid diamides, or anthranilic acid diamides; however, they are used mostly for agricultural pests, not for disease vectors. ${ }^{14,38}$ Finally, another type of synthetic 
insecticides is growth regulators (GR). It regroups synthetic products called juvenoids that mimic the juvenile hormone (JH) (review in Ref. 39) and chitine inhibitors (see Ref. 40). So far, only few cases of resistance have been reported in houseflies and mosquitoes (e.g., resistance to methoprene, a JH analog in the mosquito Ochlerotatus nigromaculi). ${ }^{41}$

In summary, most often only PYRs are available, essentially for economic cost reasons: the most recent PYR had been introduced in mid-1980s and no new synthetic insecticide has been found since mid-1990s. The shrinking availability of insecticides as a result of resistance is exacerbated by the removal from the market of insecticides that are no longer registered for public health use: some compounds are too costly, and insecticide use is restricted by regulatory agencies, due to environmental concerns. Consequently, new environment-proof products (high selectivity, no effects on nontargets) are now required for sustainable vector control. ${ }^{42}$

\subsection{Alternative Insecticides}

Environmental pollution concerns and unresolved issues pertaining to the toxicity of synthetic insecticides to humans and nontarget species have led the public and researchers' interest to investigate alternative "biological" insecticides. ${ }^{43}$ Three main types of these alternative insecticides are documented: (1) bacterial toxins, (2) essential oils, and (3) fungi.

There are two main sources of bacterial toxins: Bacillus sphaericus (Bs) and $\mathrm{Ba}$ cillus thuringiensis $(\mathrm{Bt})$. They kill insect larvae by producing proteic toxins binding to various receptors on midgut epithelial cells (review in Ref. 39). Bs toxicity is due to a binary toxin, whereas Bt toxicity is due to the interaction of four different toxins. These larvicides are presented as highly specific and effective at low doses, and are thus expected to be safe for the environment. Toxins extracted from Bs and a variety of $\mathrm{Bt}$ (B. thuringiensis var israelensis or Bti) are used for mosquito control. In these species, bacterial toxins show some differences in specificity: Bti is more effective against Aedes and Culex species than against Anopheles, whereas $\mathrm{Bs}$ is more effective against Culex than Anopheles species, and has no effect on Aedes species that lack receptors. While the presence of several toxins was expected to delay resistance apparition, Bs and Bti resistances have been detected in various mosquitoes, ${ }^{43-45}$ and resistance to $\mathrm{Bt}$ has been detected in several agricultural pests. ${ }^{46}$

Although less documented, essential oils are investigated as potential biological larvicides. They are advocated to be more specific than synthetic insecticides, and biodegradable, thus with reduced impact on the environment. Variable efficacies seem to represent a restraint for pest control; identifying the bioactive components instead of raw products could be the solution to this problem (for review see Ref. 47).

Finally, fungi can be used as biological insecticides: they target the adult stage of mosquitoes and are used essentially for malaria control. The fungus Metarhizium anisopliae has been shown to reduce An. gambiae adult life span in the laboratory and in the field in Tanzania, ${ }^{48}$ while Beauveria bassiana decreases the survival of 
another malaria vector, Anopheles stephensi. ${ }^{49}$ These agents have several advantages: they are cheap, easily stored for long term, and specific to insects. These fungal insecticides have a direct effect on Plasmodium transmission and are expected to decrease malaria prevalence. Finally, their acting late in life is considered by several authors to be an important advantage, as it will decrease selective pressure and reduce the risk of resistance development (potentially "evolution-proof" insecticides ${ }^{42,50,51}$ ).

To conclude this part, it should be noted that insecticide resistance does not appear in all treated species, at least on the short term. This can be linked to the particular life cycle of the species or to molecular constraints preventing the evolution of resistance mechanism. For example, after decades of treatment, the tsetse flies (Glossina sp.) have not yet developed resistance to DDT or PYRs, probably due to their very small number of youngs, which limits their evolutionary reactivity. ${ }^{1,10,52}$ Similarly, for several years, Aedes aegypti did not develop the most efficient resistance mechanism to OPs and CXs (i.e., insensitiveAChE) because its particular codon usage prevented the apparition of the required mutation ${ }^{53}$; the presence of the mutation was, however, described in India in 2015. ${ }^{54}$ This last example shows that understanding why resistance occurs or not also requires elucidating the mechanisms of insecticide resistance at the molecular and biochemical levels.

\section{Mechanisms of Resistance}

The targets of most insecticides are critical proteins of the insect nervous system. Insecticides bind to specific sites on their targets and disrupt their function. Any mechanism that decreases the insecticide effect will lead to resistance. This encompasses reduced penetration of the insecticide, increased excretion or sequestration of the insecticide, increased metabolism of the insecticide, and finally target modification that limits the binding of the insecticide. However, a behavioral change resulting in a reduced exposure to the insecticide can also be viewed as a resistance mechanism, if it is heritable: for example, Anopheles mosquitoes have been reported to have changed their blood-feedings habits, by seeking hosts outdoor (exophily and exophagy) rather than indoor (endophily and endophagy ${ }^{16-20}$ ); however, whether this behavior is heritable remains debated.

The first three mechanisms are poorly documented and do not seem to play a prominent role in resistance. ${ }^{55}$ Most studies aiming at understanding the mechanisms and the genetic bases of insecticide resistance focus on metabolic resistance and targetsite modification. Usually, these resistances are explained by a limited number of mechanisms, monogenic in the case of insecticide target modifications.

In this chapter, we present the various documented mechanisms of resistance. We specifically focus on disease vector species, although many mechanisms are common to agricultural pests. We insist on the evolutionary aspects of resistance, while the detailed mechanisms are treated more succinctly, and only for the major ones. More comprehensive reviews can be found (e.g., Refs. 27,35,39,55-57). Moreover, the recent explosion of genomic studies on resistance frustrates any pretention to exhaustiveness. 


\subsection{Metabolic Resistance}

Metabolic resistance regroups the various mechanisms that lead to the degradation of the insecticide in less- or nontoxic products, thus decreasing the quantity of toxic molecules that reach the target. These so-called "detoxification enzymes" belong mainly to three large gene families, cytochrome P450 monooxygenases (P450s or CYPs for genes), glutathione S-transferases (GSTs), and carboxylesterases (COEs), and most studies focus on a small set of genes. Genomic studies can, however, access mechanisms that had previously proven intractable. They allow deeper description of known resistance gene families and help find new candidate genes. They have suggested that other enzyme families may be implicated, such as UDP-glycosyl-transferases (UGTs), sulfotransferases, aldehyde dehydrogenases, NADH-cytochrome $b$ reductases, NADH dehydrogenases, NADH-ubiquinone oxidoreductases, nitrilase thioredoxin peroxidases, and cuticular genes (e.g., Refs. 56,58-60). However, in most cases the causal role of the candidates remains to be formally validated.

Detoxification enzymes are frequently divided into phase I and phase II enzymes depending on their role in detoxification pathways with hydrolases and oxidases acting during phase I, and transferases acting during phase II. ${ }^{60}$ These enzymes can act individually, synergically, or sequentially through complex insecticide degradation pathways. Such complexity is accentuated by the redundancy of insect detoxification systems. A given detoxification enzyme may indeed metabolize different insecticides (although with different kinetic parameters), thus contributing to cross-resistance. On the other hand, different enzymes may degrade the same insecticide, and contribute in an additive manner to the resistance phenotype. In natural populations, several metabolic mechanisms can be present in the same species (e.g., Ref. 61), and metabolic resistance often combines with target-site modifications leading to high-resistance levels and complex cross-resistance patterns.

\subsubsection{Glutathione S-Transferases}

Various xenobiotics contain the tripeptide glutathione; GSTs catalyze the reaction of the sulfhydryl group of this tripeptide. This sulfhydryl group reacts with electrophilic sites on xenobiotics, leading to formation of conjugates that are more readily excreted and typically less toxic than the parent insecticide. In addition to this direct detoxification, GSTs play a role in phase II detoxification (see later).

GST enzymes are present in most insects. They represent a large family of generalist detoxifying enzymes (six classes of GSTs have been identified in the genome of An. gambiae) and have thus broad substrate specificities. The GST family expands either by alternative splicing or by local gene duplication, the last leading to clusters of GST genes.

GSTs are primarily associated with resistance to OCs, particularly DDT, and OPs. GST-based resistance seems to be associated with an increased amount of enzyme resulting from gene duplication or, more often, upregulation. A constitutive GST overexpression was frequently reported in mosquito populations showing elevated resistance level to DDT. ${ }^{55,61-63}$ Quantitative genetic analyses identified a quantitative 
trait locus (QTL) for resistance to DDT in An. gambiae, within which there is a cluster of eight GSTs. ${ }^{64}$ Among them, GSTE2 was then shown to metabolize DDT. ${ }^{63}$ GSTE2 ortholog in Ae. aegypti and An. funestus was further shown to metabolize DDT. 55,66

GSTs are also suspected to play a role in the resistance to PYRs in mosquitoes through sequestration. Lumjuan et al. ${ }^{67}$ showed that the partial KD of Ae. aegypti GSTE2 and GSTE7 led to an increased susceptibility to the PYR deltamethrin. Similarly, Riveron et al. ${ }^{66}$ show that GSTE2 contributes to PYR resistance in An. funestus probably through sequestration.

\subsubsection{Cytochrome P450 Monooxygenases}

Cytochrome P450 monooxygenases (P450) are heme-thiolate enzymes found in all living organisms. ${ }^{68}$ They are best known for their monooxygenase activity, but they can catalyze a wide range of reactions. In insects, P450s are associated with the metabolism of endogenous compounds, such as hormones, and are involved in the phase I detoxification of a variety of xenobiotics including plant toxins, pollutants, and chemical insecticides. ${ }^{57,69,70} \mathrm{P} 450$ s are frequently represented by more than a 100 genes in insect genomes, so that the identification of those involved in insecticide resistance is challenging. Some of them are inducible by xenobiotics and expressed at higher level in classical detoxification tissues (midgut, fat bodies, Malpighian tubules), although such properties do not ensure their actual contribution to insecticide resistance. Insecticide resistance is often linked to the overexpression of one or multiple P450s through upregulation or gene amplification, although mutations may also lead to resistance.

P450s have been reported as responsible for resistance to most insecticide classes, particularly DDT, PYRs, and CXs. In addition, some P450s are also capable of activating particular OPs, such as malathion and diazinon (i.e., they become toxic when oxidized). The contribution of P450s in insecticide resistance can be estimated by combining the exposure of insects to the $\mathrm{P} 450$ inhibitor piperonyl butoxide (PBO) and subsequent bioassays with insecticides: if $\mathrm{P} 450 \mathrm{~s}$ are implicated, the resistance level is usually decreased in the presence of PBO. However, PBO does not equally inhibit all $\mathrm{P} 450 \mathrm{~s}$, so that absence of $\mathrm{PBO}$-induced resistance decrease does not mean that no P450 is implicated. The role of P450s in resistance may also be evidenced by biochemical assays measuring either the global heme content, ${ }^{10}$ or more specific enzyme activities using known P450 substrates, such as ethoxycoumarin (ECOD method) or resorufin (EROD method). However, biochemical assays are not always capable of detecting P450-based resistance, because these assays have a low specificity, unlike some P450s.

Following the sequencing of mosquito genomes and the development of microarrays, ${ }^{61}$ transcriptomics has been intensively used for detecting overtranscribed P450s in resistant populations, leading to the identification of several CYP genes associated with resistance in mosquitoes and other insects (reviews in Refs. $27,55,57,71,72)$. In mosquitoes, some of them were validated as capable of contributing to insecticide metabolism by functional approaches, such as heterologous expression followed by in vitro insecticide metabolism, RNA interference, or transgenic expression. These include the Anopheles genes CYP6Z1, CYP6M2, CYP6P3, 
CYP6Р9, CYP6Р4, CYP6Р7, CYP6АA3 ${ }^{73-78}$; Aedes genes CYP9J32, CYP9J24, CYP9J28, CYP6BB2 ${ }^{79-81}$; and the Culex gene CYP9M10. ${ }^{82}$ Interestingly, it was shown that Anopheles CYP6M2 and CYP6P3 can metabolize insecticides from different classes, supporting the role of $\mathrm{P} 450$ s in cross-resistance, and raising concerns for insecticide-resistance management. ${ }^{74,83}$ Although gene expression studies have identified multiple P450s overexpressed in resistant insects, very few data are available on the genetic factors controlling their overexpression. Recently, the use of targeted deep sequencing allowed the identification of gene amplifications controlling the overproduction of P450s in multiple PYR-resistant population of Ae. aegypti worldwide. ${ }^{60}$ High-throughput sequencing approaches also allowed identifying nonsynonymous variations affecting P450s potentially linked to insecticide detoxification. ${ }^{60}$

\subsubsection{Carboxylesterases}

More than 30 genes coding COEs are found in insects (see detailed review in Refs. 26,39). Most COEs are serine esterases, that is, they have a serine residue within a catalytic triad necessary for hydrolysis. COEs bind to an ester group and then break the ester bound by a process of acylation-deacylation. Multiple forms of COEs are found in insects, with broad and overlapping substrate specificities.

The majority of insecticides, including almost all CXs and OPs, most PYRs, and some GRs bear ester groups. In most cases, hydrolysis of the ester group leads to a reduced toxicity of the insecticide. Consequently, COEs are often involved in metabolic resistance mechanisms, although the level of resistance conferred is relatively low $(\sim 10 \times)$ compared to target-site resistance. As for P450s, the role of COEs in resistance is usually diagnosed by the addition of a synergist, the S,S,S-tributyl phosphorotrithioate (DEF) to bioassays. DEF inhibits COEs (but also GSTs): if COEs contribute to resistance, insecticide toxicity is expected to increase in the presence of DEF, significantly more in resistant than in susceptible insects. ${ }^{84}$ COE-based resistance has been detected in various species, mainly against OPs and to a lesser extent to PYRs. ${ }^{10,15}$

OP resistance in Culex mosquitoes is generally caused by an elevated COE protein quantity, up to 80 times the level found in susceptible individuals. ${ }^{85}$ Two esterases, $\alpha$-esterase (or esterase A) and $\beta$-esterase (or esterase B), have been recognized based on their higher affinity for, respectively, $\alpha$ - and $\beta$-naphthylacetate. ${ }^{86}$ Their overexpression is usually caused by an increased gene copy number (gene amplification) of one or both esterases, although upregulation may also contribute to overexpression. ${ }^{87,88}$ The loci coding for the esterases A and B behave as a single locus named Ester ${ }^{89}$ The number of gene copies within an amplification of the Ester locus can vary greatly, potentially in relation with the intensity of insecticide treatments. ${ }^{84,90,91}$

Amplified esterases have also been described in the mosquitoes An. gambiae and Ae. aegypti in association with resistance to the OP temephos. ${ }^{92,92 a}$ Orthologs of these genes were also found amplified in association with temephos resistance in the tiger mosquito Ae. albopictus. ${ }^{93}$ Biochemical assays also pointed out the role of esterases in PYR hydrolysis in mosquitoes, ${ }^{94}$ although no particular esterase has yet been validated as able to hydrolyze PYRs. Moreover, it appears that the PYR metabolites 
produced by esterases could be further metabolized by overexpressed P450s of the subfamily CYP6Z in PYR-resistant populations, suggesting synergy between these two resistance mechanisms. ${ }^{77}$

Because overexpressed COEs can represent a large percentage of the total protein of the insect (up to $12 \%$ of the soluble proteins in some resistant mosquitoes ${ }^{95}$ ), it is difficult to disentangle their sequestration effect (i.e., binding to the insecticide without hydrolysis) from the direct hydrolysis of the insecticide. This appears to depend on the species and the esterase allele: hydrolysis appears predominant in the aphid E4 esterase, while in mosquitoes the Ester ${ }^{B I}$ and $E s t e r^{2}$ alleles rather sequester the insecticide and show a lower hydrolysis activity. ${ }^{96-98}$ However, qualitative changes affecting COEs may also be responsible for resistance to particular insecticides. For example, resistance to the OP malathion in Anophelinae, Musca domestica and Lucilia cuprina, was associated with particular point mutations inducing a faster hydrolysis.

In terms of population genetics, $\mathrm{COE}$ resistance to OPs in C. pipiens is probably one of the best-studied cases. In this species, resistance to OPs was monitored since late 1960s in the Montpellier area of Southern France. ${ }^{100-102}$ This long-term monitoring showed that several Ester-resistance alleles have been replacing each other across time: Ester ${ }^{1}$ was the first detected resistance allele in 1972, then Ester ${ }^{4}$ in 1986, and finally Ester ${ }^{2}$ arrived by migration in 1991. These alleles were selected in insecticide-treated areas, but also showed a fitness disadvantage or cost in absence of insecticide (lower mating success, lower survival, and so on). ${ }^{103-108}$ The quantification of their fitness cost showed that the various alleles correspond to different fitness tradeoffs: Ester ${ }^{4}$ was first favored over Ester ${ }^{l}$ because of a lower cost (selection for a generalist allele). Then Ester ${ }^{2}$ appeared to be replacing the first two alleles because it confers a higher resistance level, despite its relatively high cost (selection for a specialist allele ${ }^{102}$ ). Overall, this example confirms that insecticide resistance is a dynamic process, as new haplotypes can be selected for adjusting the resistance phenotype and the fitness of resistant individuals to insecticide pressures and environmental factors.

\subsection{Target-Site Modification}

Resistance by target-site modification is due to point mutations in the insecticide target gene that results in reduced binding of insecticides, rather than to a change in expression level. Because most insecticide targets are vital molecules, there is generally only a limited number of mutations in the target able to decrease insecticide affinity without impeding its original function to an unsustainable degree (see detailed review in Ref. 39). A mutation conferring resistance while partly impairing the target's normal function leads to a fitness cost.

\subsubsection{GABA Receptors}

GABA is a major neurotransmitter in the insect's central and peripheral nervous system and in neuromuscular junctions. The GABA receptors are linked to chlorine-gated channels, causing hyperpolarization that blocks the nervous influx. GABA receptors 
are the target of CDs. CDs are noncompetitive inhibitors that bind to a site on the receptor close to the chlorine-gated channel, stabilizing it in an inactive closed state. This induces an overexcitation by removal of the inhibition, and leads to convulsions and death of the insect. GABA receptors have also secondary-binding sites for some PYRs or insecticides of the avermectin family. ${ }^{10}$

Resistance to CDs is due to a decreased sensitivity to insecticide of the GABA receptor A, through a point mutation causing an amino acid change in the receptorcoding gene. This gene, called $R d l$ (Resistance to dieldrin, the most-used CD), has been first cloned in Drosophila melanogaster. In all D. melanogaster-resistant individuals, the $R d l$ locus displays a similar mutation at position 302 in the channel-lining domain sequence, changing an alanine into a serine (A302S). The role of this mutation in $\mathrm{CD}$ resistance was confirmed by directed mutagenesis. The serine residue occupies the insecticide-binding site of the GABA receptor and destabilizes its conformation (review in Ref. 109). The resistance allele $\left(R d l^{R}\right)$ is semidominant and can confer cross-resistance to other insecticides, such as fipronil (e.g., Refs. 56,109).

Due to an extensive use of CDs before their banning in the 1980s, resistance has been selected in several insect species, which all display a mutation at the same position (A302S or A302G). ${ }^{56,109}$ Whether these mutations are costly depends on species: a fitness cost associated with resistance has been identified in L. $_{\text {cuprina }}{ }^{110}$ and has been suggested in $C$. pipiens and An. albopictus, ${ }^{111,112}$ but no cost has been found in D. melanogaster, ${ }^{109}$ even if resistance affects temperature sensitivity. The $R d l$ locus has been found duplicated in the greenbug Myzus persicae ${ }^{113}$ and in a strain of D. melanogaster. ${ }^{114}$ In the latter, a tandem duplication of $113 \mathrm{~kb}$ associates a susceptible and a resistance copy of the locus. The phenotype associated to this duplication was shown to be close to that of a standard heterozygote, namely an intermediate resistance level and a reduced heat shock recovery time. ${ }^{114}$

\subsubsection{Voltage-Gated Sodium Channels}

Nerve action potentials are transmitted by a wave of depolarization along the neural axon. They are due to the movement of sodium ions $\left(\mathrm{Na}^{+}\right)$crossing the axonal membrane through the opening of voltage-gated sodium channels (VGSCs), and stop when these channels are inactivated. VGSCs are glycoproteins with a pore for ion transport and can adopt three different states: resting, open, or inactivated; the $\mathrm{Na}^{+}$ions pass only when the channels are open. ${ }^{115}$

VGSC are the targets of DDT and PYRs. When these insecticides bind to the VGSC, they slow their closing speed, prolonging the depolarization. ${ }^{115-117}$ The intensity of the effect is dose-dependent, proportional to the number of Na-channels inactivated. ${ }^{115}$ For PYRs, the magnitude of the effect depends on the type of insecticide molecules, type I (e.g., permethrin) or type II (e.g., lambda-cyhalothrin and deltamethrin), which, respectively, lack or not a cyano group. During action potential, type II PYRs lengthen the sodium flux more than type I, and thus usually display a more intense effect. ${ }^{116}$ At the phenotypic level, inactivation of VSGC results in a rapid KD effect, the insect being incapacitated for some time, followed by recovery or death, 
depending on the species and development stages (in mosquitoes, the adults tend to recover, while larvae will drown).

One major mechanism, named knockdown resistance (kdr), is responsible for PYR and DDT resistance, by reducing the receptors sensitivity (binding capacity) to these insecticides and modifying the action potential of the channel. ${ }^{39,117,118}$ First discovered in $M$. domestica, this mechanism has been described in many agricultural pests and vectors. This resistance mechanism has several consequences: it decreases the irritant and the repellent effects, and either cancels or reduces the KD effect. ${ }^{119}$

Extension mutations affecting the VGSC gene are called $k d r$ mutations. By sequencing the VGSC protein ( $>2000$ amino acids), the first two $k d r$ mutations were identified in $M$. domestica, both in the second protein domain. The first one (L1014F) is associated with moderate $(10-30 \times)$ PYR resistance; the second (M918T, also called super-kdr) is always associated with the L1014F and confers a higher resistance (up to $500 \times$ ). ${ }^{120}$ Substitution of the L1014 is found in a large variety of species (L1014F or L1014S, and also L1014H in Heliothis virescens) and corresponds to the $k d r^{R}$ alleles. ${ }^{116,117,121,122}$

The phenotype conferred by $k d r^{R}$ is recessive or semirecessive, ${ }^{10,119}$ with higher resistance to type I than type II PYRs. ${ }^{123}$ However, the various mutations show some specificity, as L1014F confers a high resistance to both DDT and permethrin (PYR), while L1014S confers a lower resistance to permethrin than to DDT. ${ }^{121,124}$ Other $k d r$ mutations (about 30 in total) have been described in various species, including super-kdr mutations. ${ }^{116,117}$ Some of these mutations are conserved over a large array of organisms, while others are more specific and unique. In Ae. aegypti, the $k d r$ phenotype has been observed, but it appears that a codon bias prevents the appearance of any L1014 mutation. ${ }^{125}$ However, several other mutations have been observed associated with resistance in Ae. aegypti (e.g., V1023G/I, I1018 M/V, F1565C, D1794Y, or S996 ${ }^{126}$ ). In Ae. albopictus, the F1565C mutation has been observed, while no mutation has been found at the 1018 site. ${ }^{81}$ The importance of these various mutations in the different resistance phenotypes is thus still in debate.

The role of the L1014 F/S mutations $\left(k d r^{R}\right)$ as the sole cause of the $k d r$ phenotype is still discussed. ${ }^{127} k d r^{R}$ is clearly associated to PYR and DDT resistance in Blatella germanica, C. pipiens, houseflies, hornflies, and some moths (review in Ref. 128). In An. gambiae, although metabolic resistance is often present, high resistance to PYR and DDT is most of the times associated with a high $k d r^{R}$ frequency, and resistant insects carry at least one $k d r^{R}$ copy. ${ }^{124,129-132}$ Moreover, $k d r^{R}$ frequency usually increases when PYRs are used ${ }^{133-135}$ : two alleles are spreading in An. gambiae in Africa, L1014F and L1014S mutations and analyses of the noncoding regions of the $k d r$ gene suggest that the two alleles occurred several times independently (at least three times for L1014F and two times for L1014S ${ }^{122,136,137}$ ). Similarly, in West African C. p. quinquefasciatus, resistance frequency follows a gradient of treatment intensity.

In the field, An. gambiae resistance to PYRs through $k d r$ can lead to reduced repellent effect and decreased mortality. For example, $k d r^{R}$ frequency is high in Benin and Côte d'Ivoire, while no other PYR-resistance mechanism was found (although they could have been overlooked): studies have shown strong diminution of vector control 
with PYR-treated bed nets in these countries. ${ }^{138}$ In contrast, other studies have found that despite the high correlation between $k d r$ mutations and PYR resistance, PYRtreated bed nets remained somewhat efficient against resistant An. gambiae. ${ }^{127,139}$ This could be due to the ability of resistant mosquitoes to stay on a treated bed net longer than susceptibles, and thus absorb a high-enough quantity of insecticide to be killed. ${ }^{119}$ For example, in Kenya, the use of PYR-treated bed nets increased $k d r^{R}$ frequency, but had no impact on malaria and mosquito population densities, as both decreased in treated and untreated villages. ${ }^{133}$ Similarly two studies found that $k d r^{R}$ alone (i.e., in the absence of metabolic resistance) did not reduce bed net efficiency against resistant An. stephensi, despite a reduced KD effect. ${ }^{140}$ The issue of the impact of $k d r$ resistance on PYR-treated bed net efficiency to control malaria thus remains hotly debated.

\subsubsection{Acetylcholinesterase}

In the cholinergic synapses of invertebrate and vertebrate central nervous system, AChE terminates the synaptic transmission by rapidly hydrolyzing the neurotransmitter acetylcholine (ACh). AChE is the target of OPs and CXs insecticides, which are competitive inhibitors of ACh: when they bind to AChE, their very slow release prevents hydrolysis of the natural substrate. Consequently, ACh remains active in the synaptic cleft and the nervous influx is continued, leading to insect death by tetany.

In most insects there are two genes, ace-1 and ace-2, coding for AChE1 and $\mathrm{AChE} 2$, respectively. In these species, AChE1 is the main synaptic enzyme while the physiological role of AChE2 is still uncertain. Diptera of the Cyclorrapha group or "true" flies (such as D. melanogaster and M. domestica) possess a single AChE, which is encoded by the ace-2 gene and is the synaptic enzyme in that case. Phylogenetic analyses have shown that the presence of two ace genes is probably the ancestral insect state. $^{141,142}$

The first molecular studies on an insensitive AChE conferring resistance to OPs and CXs were carried out on D. melanogaster. Several mutations were identified, each giving a low resistance when alone, and a higher resistance when in combination. ${ }^{143}$ Similar results were later found with other Diptera that have only the ace-2 gene (e.g., M. domestica ${ }^{26}$ ).

In mosquitoes where $\mathrm{AChE1}$ is the synaptic enzyme, the most common resistance mutation (G119S) in the ace-1 gene is located just near the active site. In C. pipiens, G119S occurred at least 3 times independently, once in $C$. p. pipiens and twice in $C . p$. quinquefasciatus. ${ }^{53,144,145}$ However, two other mutations in ace- 1 have been identified, both close to the active site: (1) F331W has been observed only in Culex tritaeniorhynchus, ${ }^{146,147}$ (2) F290V has been observed only in C. p. pipiens. ${ }^{148,149}$ The type of mutation appears highly constrained by the codon use: until recently the G119S mutation was never found in Ae. aegypti, Ae. albopictus, or C. tritaeniorhynchus, probably because it requires two mutational steps. ${ }^{53}$ It was, however, described in Ae. aegypti from India in 2015, apparently through a mutation from a different codon $\left(\mathrm{R} 119 \mathrm{~S}^{54}\right)$. 
The ace mutations are responsible for a decreased inhibition of the AChE by the insecticides. ${ }^{150}$ There are only few resistance mutations observed in various species, suggesting high constraints: those observed in the field are within the active gorge of the enzyme and cause steric problems with bulkier side-chains, while other substitutions (lab-engineered) often result in the inability of enzyme to degrade $\mathrm{ACh} .{ }^{26} \mathrm{The}$ G119S ace-1 mutation has recently been shown to interact synergistically with an unknown sex-linked gene to allow a $>40000$-fold resistance to chlorpyrifos $\left(\mathrm{OP}^{151}\right)$. Similarly, the G119S mutation associated with the $k d r^{R}$ allele confers higherresistance levels in An. gambiae to both OPs and CXs insecticides. ${ }^{152}$

The evolution of insensitive AChE1 has been studied in depth in the mosquitoes C. pipiens and An. gambiae. In C. pipiens, it was first detected in Southern France in 1978, 9 years after the beginning of OP treatments. ${ }^{153}$ The gene coding for this G119S mutated AChE1 (ace-1 $1^{R}$ ) rapidly spread in treated natural populations. However, its frequency remained low in adjacent untreated areas connected by migration, indicating a fitness cost associated with ace $-l^{R} .{ }^{104}$ The $>60 \%$ reduction of AChE1 activity in G119S-resistant mosquitoes ${ }^{154}$ may probably explain, at least partially, this cost, which is expressed phenotypically through various developmental and behavioral problems in individuals carrying ace- $I^{R}$. ${ }^{105,107,108}$ Similarly, the F290V mutation is probably associated with a fitness cost, although it does not appear to be due to activity reduction. ${ }^{149}$ Several independent heterogeneous duplications of the ace- 1 gene, putting a susceptible and a resistant copy in tandem $\left(\right.$ ace $-I^{D}$ ), have been identified in C. p. pipiens and C. p. quinquefasciatus. ${ }^{145,155}$ These alleles are thought to be selected because they confer an alternative fitness trade-off, that is, reducing the cost of the ace- $I^{R}$ allele, but with a decreased resistance level as well. ${ }^{156}$ However, some ace- $I^{D}$ can be associated to extremely deleterious phenotypes when homozygotes. ${ }^{156,157}$ Several other duplications have been observed recently in the Mediterranean area, with a F290V copy instead of a G119S copy. ${ }^{149}$ In An. gambiae, the occurrence of ace- $1^{R}$ has been detected in several West African countries, and this allele is probably spreading from a single origin. ${ }^{144,158,159}$ As in C. pipiens, this mutation is associated with a strong selective cost in An. gambiae. ${ }^{160}$ A duplication carrying a G119S copy has also been found, and appears to follow the same trajectory as in C. pipiens ${ }^{161}$; the An. gambiae ace $-1^{D}$ allele also provides an alternative phenotype, a reduced cost associated with a reduced resistance. ${ }^{160}$ In both species, it has been suggested that the relative fitness of the two alleles $\left(\right.$ ace $-1^{R}$ and $\left.a c e-1^{D}\right)$ may depend on the intensity of insecticide treatments. ${ }^{156,160}$ Finally, two studies reported in 2015 have suggested that resistance alleles with multiple ace- $1^{R}$ copies are segregating in Africa ${ }^{162,163}$; the fitness consequences of such duplications remain, however, unknown.

\subsection{Other Resistance Mechanisms}

\subsubsection{Growth Regulators}

Juvenoids mimic JH and disrupt insect development. Few resistance cases have been described in various species (review in Ref. 39). High resistance to methoprene has 
been described in the mosquito Ochlerotatus nigromaculis in California, potentially through target-site mutation, ${ }^{41}$ while a 7.7 -fold resistance to the same insecticide has been reported in C. p. pipiens from New York. ${ }^{45}$

\subsubsection{Toxin Receptors}

Bt toxins have a complex mode of action not clearly understood. Bt resistance is increasing in the field in several pests. ${ }^{46}$ Presently, the only report of field resistance in mosquito is a 33-fold resistance to Bti (Bt var. israelensis, the only Bt variety active on mosquitoes) detected in a natural population of $C$. p. pipiens from New York. However, the mechanism of this resistance was not investigated. ${ }^{45}$ Genomic studies suggested several candidates for Bti resistance in Ae. aegypti, but they are not yet validated. ${ }^{164}$ Finally, it appears that depending on the environmental conditions, some of the four Bti toxins may be inactivated, ${ }^{165}$ which could favor the emergence of full Bti resistance through intermediate bouts of selection to each toxin independently.

For Bs toxins, resistance has been described essentially in mosquitoes of the C. pipiens complex, due to mutation in the toxin receptor. It developed very rapidly within the first year of treatment in India $\left(10-155 \times\right.$ resistance $\left.^{43}\right)$ and in Tunisia $\left(S p-T\right.$ gene, $>5000 \times$ resistance $\left.^{166}\right)$. Similarly, control using Bs toxins started in the early 1990s in Southern France and first failure was reported in 1994 in Port-Louis (near Marseille). This resistance $(>10,000 \times)$ was due to a recessive sex-linked gene, named $s p-1$. In 1996, Bs resistance was reported close to the Spain border (Perpignan, $200 \mathrm{~km}$ away from Port St Louis); it was due to a second gene, $s p$-2, which was recessive and sex-linked. ${ }^{167}$ Now Bs resistance has been observed worldwide in the $C$. pipiens complex. ${ }^{43}$ Two of the alleles identified $\left(s p-2^{R}\right.$ and an allele selected in a laboratory strain from California ${ }^{168}$ ) change the toxin receptor binding properties, and were found to be due to "stop" mutations or mobile element insertion in the toxin receptor. ${ }^{169,170}$ The effect of the other alleles is unknown. ${ }^{166}$ Bs resistance has also been selected in the laboratory in An. stephensi. ${ }^{43}$

\subsection{Resistance Generalities}

Some general patterns can be identified from the variety of mechanisms observed for insecticide resistance.

A first characteristic is that resistance evolves rapidly, with fast selective sweeps in field populations. Most of the times, resistance alleles are present in the field before insecticide treatments, at very low frequencies. They are selected locally but can spread very rapidly. A single resistance gene may have a large distribution, ${ }^{71,109,122}$ for example, the worldwide migration of Ester ${ }^{2}$ in C. pipiens. ${ }^{101}$ Alternatively, other resistance alleles have multiple origins: ace- $I^{R}$ mutations in C. pipiens $\left(\mathrm{G} 119 \mathrm{~S}^{144}\right.$ or $\mathrm{F}^{2} 90 \mathrm{~V}^{149}$ ) or $k d r$ mutations in Ae. aegypti. ${ }^{17-}$

It also seems that resistance evolution is quite constrained. For target-site resistance, most mutations are costly and compromise the performance of the native protein function, so that codon usage may prevent resistance apparition. ${ }^{53,125}$ 
Another issue is the cross-resistance. Cross-resistances between insecticide classes can be associated with the sharing of target sites. For example, $k d r^{R}$ causes cross-resistance between DDT and PYRs in An. gambiae, ${ }^{123}$ and ace- $l^{R}$ between OPs and CXs. ${ }^{150}$ Cross-resistance can even be a greater issue when considering metabolic resistance. First, different genes belonging to a same enzyme family can cause resistance to several insecticides ("gene family cross-resistance"), even from different classes: for example, different $\mathrm{COE}$ and $\mathrm{P} 450$ genes cause resistance to DDT, others to PYRs, OPs, and CXs in Anophelines. ${ }^{175}$ However, a unique gene may also be involved in resistance to several insecticides, from different classes: this is the case, for example, of the CYP6M2 gene (P450), which can metabolize both deltamethrin (PYR) and DDT $\left(\mathrm{OC}^{57}\right)$. The consequences of these crossresistances are a severe reduction of the availability of alternative insecticides, thereby gravely endangering vector control.

Finally, despite advances, a full analysis of resistance remains challenging due to the complexity of interactions, pleiotropy, and redundancy when several resistance mechanisms and/or resistance genes are present in the same insect. ${ }^{39}$ Interactions between resistance loci have been studied in houseflies or mosquitoes, and most of them appear to be synergistic. Such synergies have been observed, for example, in C. pipiens between COE and ace-1 for OP resistance, ${ }^{176}$ between ace- 1 and an unknown gene, raising resistance to chlorpyrifos by more than 2000-fold compared to ace-1 alone ( $>40,000$-fold compared to susceptible ${ }^{151}$ ) and between $k d r$ and P450 for PYR resistance, ${ }^{82}$ in Ae. aegypti between repellents (DEET) and $\mathrm{CXs},{ }^{177}$ in An. gambiae s.s. between $a c e-1$ and $k d r$ for OPs and CXs resistance ${ }^{152}$ or in three Anopheles species between PYR resistance and susceptibility to fungus applications. ${ }^{42}$ Moreover, these interactions may vary with environmental conditions (positive synergism for resistance in treated area but negative synergism for cost in nontreated areas) or with the genetic background of the insect. ${ }^{82}$ For example, the presence of $k d r^{R}$ decreases the cost of ace- $I^{R}$ in C. pipiens. ${ }^{178}$

\section{Conclusion}

The natural history of mosquito-borne diseases is complex, and the interplay of climate, ecology, vector biology, and many other factors defies simplistic analyses. The recent resurgence of many of these diseases is a major cause for concern. Its principal determinants are politics, economics, and human activities (rather than climate change). In order to control these diseases and ameliorate the socioeconomic burden they cause in developing countries, vector control remains a powerful and accessible tool. However, any disease control strategy should take into account insecticide-resistance management as it can greatly impact its success (vector control failures) and may have a direct effect on pathogen transmission. ${ }^{179-182}$ This includes first establishing a continuous survey of resistance at a local scale by implicating the local population, a difficult but essential task to set goals and evaluate success. Several survey sites in different conditions are required for sentinel 
purposes, together with some baseline information, to rapidly detect resistance, identify the mechanisms, and change the policies adequately. ${ }^{183}$ In order to achieve this survey, basic tools, such as bioassays, remain most powerful, and should always be a preliminary step before more complex and more costly analyses. However, specific and validated molecular markers for the known resistance alleles (e.g., $k d r$, ace-1, and some metabolic markers) are also required to rapidly identify the origin and follow the dynamics of resistance at a minimum cost. These local surveys should then be integrated at a more global scale for vector control coordination, allowing informed decisions for using alternative tools to insecticides and preserving the remaining insecticides by carefully planning their use to minimize resistance selection. Clearly, the greatest challenge for successful vector and disease control is the coordination of the different actors (chemical industries, researchers, politics, control agencies, and local populations), which do not have the same agendas, motivations, or economical interests.

Besides its implications in public health and development, insecticide resistance remains a powerful evolutionary biology model to study the contemporary adaptation of organisms to a changing environment. It indeed allows a complete and integrative study, from the molecular mechanisms to the fitness consequences at the individual level and their impacts on insect population dynamics and interactions with pathogens. Moreover, it is for once pleasant to see that these rather fundamental approaches of evolutionary biology may have a direct impact in the society and help design new strategies for the successful control of some of the most threatening human diseases. ${ }^{50}$

\section{References}

1. WHO. Pesticides and their applications for the control of vectors and pests of public health importance. 6th ed. World Health Organization; 2006.

2. WHO. World health statistics. 2015.

3. Tolle MA. Mosquito-borne diseases. Curr Probl Pediatr Adolesc Health Care 2009;39: 97-140.

4. Enserink M. Entomology: a mosquito goes global. Science 2008;320:864-6.

5. Kay B, Vu SN. New strategy against Aedes aegypti in Vietnam. Lancet 2005;365:613-7.

6. Ooi E-E, Goh K-T, Gubler DJ. Dengue prevention and 35 years of vector control in Singapore. Emerg Infect Dis 2006;12:887-93.

7. Morrison AC, Zielinski-Gutierrez E, Scott TW, Rosenberg R. Defining challenges and proposing solutions for control of the virus vector Aedes aegypti. PLoS Med 2008;5:e68.

8. Cheesman DF. Varro and the small beasts: a bimillennium for microbiologists. Nature 1964;203:911-2.

9. Roberts DR, Andre RG. Insecticide resistance issues in vector-borne disease control. Am J Trop Med Hyg 1994;50:21-34.

10. Hemingway J, Ranson H. Insecticide resistance in insect vectors of human disease. Annu Rev Entomol 2000;45:371-91.

11. Beier J, Keating J, Githure JI, Macdonald M, Impoinvil D, Novak R. Integrated vector management for malaria control. Malar J 2008;7:S4. 
12. Dialynas E, Topalis P, Vontas J, Louis C. Miro and IRbase: IT tools for the epidemiological monitoring of insecticide resistance in mosquito disease vectors. PLoS Negl Trop Dis 2009;3:e465.

13. Georghiou GP, Lagunes-Tejeda A. The occurrence of resistance to pesticides in arthropods. Rome: Food and Agriculture Organization; 1991.

14. Whalon ME, Mota-Sanchez D, Hollingworth RM. Global pesticide resistance in arthropods. Cambridge, MA: CABI Publishing; 2008.

15. Nauen R. Insecticide resistance in disease vectors of public health importance. Pest Manag Sci 2007;63:628-33.

16. Reddy MR, Overgaard HJ, Abaga S, Reddy VP, Caccone A, Kiszewski AE, et al. Outdoor host seeking behaviour of Anopheles gambiae mosquitoes following initiation of malaria vector control on Bioko Island, Equatorial Guinea. Malar J 2011;10:184.

17. Ndiath MO, Mazenot C, Sokhna C, Trape J-F. How the malaria vector Anopheles gambiae adapts to the use of insecticide-treated nets by African populations. PLoS One 2014;9: e97700.

18. Moiroux N, Gomez MB, Pennetier C, Elanga E, Djènontin A, Chandre F, et al. Changes in Anopheles funestus biting behavior following universal coverage of long-lasting insecticidal nets in benin. J Infect Dis 2012;206:1622-9.

19. Russell TL, Govella NJ, Azizi S, Drakeley CJ, Kachur SP, Killeen GF. Increased proportions of outdoor feeding among residual malaria vector populations following increased use of insecticide-treated nets in rural Tanzania. Malar J 2011;10:80.

20. Sougoufara S, Diédhiou SM, Doucouré S, Diagne N, Sembène PM, Harry M, et al. Biting by Anopheles funestus in broad daylight after use of long-lasting insecticidal nets: a new challenge to malaria elimination. Malar J 2014;13:125.

21. Wood RJ. In: Bishop JA, Cook LM, editors. Insecticide resistance: genes and mechanisms. London: Academic Press; 1981. p. 53-96.

22. Melander A. Can insects become resistants to sprays? J Econ Entomol 1914;7:167-72.

23. WHO. Global insecticide use for vector-borne disease control, a 10 year assessment (2000-2009). 2011. ISBN:9789241502153.

24. WHO. Malaria section. Bull World Heal Organ 1957;16:874.

25. Davidson G. Insecticide resistance in Anopheles gambiae Giles: a case of simple Mendelian inheritance. Nature 1956;178:863-4.

26. Oakeshott JG, Devonshire AL, Claudianos C, Sutherland TD, Horne I, Campbell PM, et al. Comparing the organophosphorus and carbamate insecticide resistance mutations in cholin- and carboxyl-esterases. Chem Biol Interact 2005;157-158:269-75.

27. Feyereisen R, Dermauw W, Van Leeuwen T. Genotype to phenotype, the molecular and physiological dimensions of resistance in arthropods. Pestic Biochem Physiol 2015;121: 61-77.

28. Carson R. Silent spring. Boston: Houghton Mifflin; 1962.

29. van den Berg H. Global status of DDT and its alternatives for use in vector control to prevent disease. Environ Health Perspect 2009;117:1656-63.

30. Brooke BD, Kloke G, Hunt RH, Koekemoer LL, Temu EA, Taylor ME, et al. Bioassay and biochemical analyses of insecticide resistance in southern African Anopheles funestus (Diptera: Culicidae). Bull Entomol Res 2001;91:265-72.

31. Rogan WJ, Chen A. Health risks and benefits of bis(4-chlorophenyl)-1,1,1-trichloroethane (DDT). Lancet 2005;366:763-73.

32. Coleman M, Casimiro SLR, Hemingway J, Sharp B. Operational impact of DDT reintroduction for malaria control on Anopheles arabiensis in Mozambique. J Med Entomol 2008;45:885-90. 
33. Elissa N, Mouchet J, Rivière F, Meunier JY, Yao K. Resistance of Anopheles gambiae s.s. to pyrethroids in Cote d'ivoire. Ann Soc Belg Med Trop 1993;73: 291-4.

34. Chandre F, Darriet F, Darder M, Cuany A, Doannio JMC, Pasteur N, et al. Pyrethroid resistance in Culex quinquefasciatus from West Africa. Med Vet Entomol 1998;12: 359-66.

35. Liu N, Xu Q, Zhu F, Zhang L, Nannan LIU, Qiang XU, et al. Pyrethroid resistance in mosquitoes. Insect Sci 2006;13:159-66.

36. Oxborough RM, Mosha FW, Matowo J, Mndeme R, Feston E, Hemingway J, et al. Mosquitoes and bednets: testing the spatial positioning of insecticide on nets and the rationale behind combination insecticide treatments. Ann Trop Med Parasitol 2008;102: 717-27.

37. Pasteur N, Sinègre G. Esterase polymorphism and sensitivity to Dursban organophosphorous insecticide in Culex pipiens pipiens populations. Biochem Genet 1975;13: 789-803.

38. Nauen R. Insecticide mode of action: return of the ryanodine receptor. Pest Manag Sci 2006;62:690-2.

39. Hollingworth RM, Dong K. In: Whalon ME, Mota-Sanchez D, Hollingworth RM, editors. The biochemical and molecular genetic basis of resistance in arthropods. Cambridge, MA: CAB International; 2008. p 192.

40. Hirose T, Sunazuka T, Omura S. Recent development of two chitinase inhibitors, Argifin and Argadin, produced by soil microorganisms. Proc Jpn Acad Ser B Phys Biol Sci 2010; 86:85-102.

41. Cornel AJ, Stanich MA, McAbee RD, Mulligan FS. High level methoprene resistance in the mosquito Ochlerotatus nigromaculis (Ludlow) in Central California. Pest Manag Sci 2002;58:791-8.

42. Farenhorst M, Mouatcho JC, Kikankie CK, Brooke BD, Hunt RH, Thomas MB, et al. Fungal infection counters insecticide resistance in African malaria mosquitoes. Proc Natl Acad Sci 2009;106:17443-7.

43. Mittal PK. Biolarvicides in vector control: challenges and prospects. J Vector Borne Dis 2003;40:20-32.

44. Nielsen-Leroux C, Pasquier F, Charles JF, Sinegre G, Gaven B, Pasteur N. Resistance to Bacillus sphaericus involves different mechanisms in Culex pipiens (Diptera: Culicidae) larvae. J Med Entomol 1997;34:321-7.

45. Paul A, Harrington LC, Zhang L, Scott JG. Insecticide resistance in Culex pipiens from New York. J Am Mosq Control Assoc 2005;21:305-9.

46. Tabashnik BE, Brévault T, Carrière Y. Insect resistance to Bt crops: lessons from the first billion acres. Nat Biotechnol 2013;31:510-21.

47. George DR, Finn RD, Graham KM, Sparagano OA. Present and future potential of plantderived products to control arthropods of veterinary and medical significance. Parasit Vectors 2014;7:28.

48. Scholte E-J, Ng'habi K, Kihonda J, Takken W, Paaijmans K, Abdulla S, et al. An Entomopathogenic fungus for control of adult African malaria mosquitoes. Science 2005;308: 1641-2.

49. Blanford S, Chan BHK, Jenkins N, Sim D, Turner RJ, Read AF, et al. Fungal pathogen reduces potential for malaria transmission. Science 2005;308:1638-41.

50. Michalakis Y, Renaud F. Malaria: evolution in vector control. Nature 2009;462:298-300.

51. Read AF, Lynch PA, Thomas MB. How to make evolution-proof insecticides for malaria control. PLoS Biol 2009;7:e58. 
52. Welburn SC, Coleman PG, Maudlin I, Fevre EM, Odiit M, Eisler MC. Crisis, what crisis? Control of Rhodesian sleeping sickness. Trends Parasitol 2006;22:123-8.

53. Weill M, Berticat C, Lutfalla G, Pasteur N, Philips A, Fort P, et al. Insecticide resistance: a silent base prediction. Curr Biol 2004;14:R552-3.

54. Muthusamy R, Shivakumar MS. Susceptibility status of Aedes aegypti (L.) (Diptera: Culicidae) to temephos from three districts of Tamil Nadu, India. J Vector Borne Dis 2015; 52:159-65.

55. Nkya TE, Akhouayri I, Kisinza W, David J-P. Impact of environment on mosquito response to pyrethroid insecticides: facts, evidences and prospects. Insect Biochem Mol Biol 2013;43:407-4013.

56. Hemingway J, Hawkes NJ, McCarroll L, Ranson H. The molecular basis of insecticide resistance in mosquitoes. Insect Biochem Mol Biol 2004;34:653-65.

57. David J, Ismail HM, Chandor-proust A, Paine MJI. Role of cytochrome P450s in insecticide resistance : impact on the control of mosquito-borne diseases and use of insecticides on Earth. Philos Trans R Soc B Biol Sci 2013;368:20120429.

58. Oakeshott JG, Home I, Sutherland T, Russell R. The genomics of insecticide resistance. Genome Biol 2003;4:202.

59. Li X, Schuler MA, Berenbaum MR. Molecular mechanisms of metabolic resistance to synthetic and natural xenobiotics. Annu Rev Entomol 2007;52:231-53.

60. Faucon F, Dusfour I, Gaude T, Navratil V, Boyer F, Chandre F, et al. Identifying genomic changes associated with insecticide resistance in the dengue mosquito Aedes aegypti by deep targeted sequencing. Genome Res 2015;25:1347-59.

61. Strode C, Wondji CS, David J-P, Hawkes NJ, Lumjuan N, Nelson DR, et al. Genomic analysis of detoxification genes in the mosquito Aedes aegypti. Insect Biochem Mol Biol 2008;38:113-23.

62. Ranson H, Hemingway J. Mosquito glutathione transferases. In: Gluthione transferases and gamma-glutamyl transpeptidases vol. 401; 2005. p. 226-41.

63. Enayati AA, Ranson H, Hemingway J. Insect glutathione transferases and insecticide resistance. Insect Mol Biol 2005;14:3-8.

64. Ranson H, Claudianos C, Ortelli F, Abgrall C, Hemingway J, Sharakhova MV, et al. Evolution of supergene families associated with insecticide resistance. Science 2002;298: 179-81.

65. Lumjuan N, McCarroll L, Prapanthadara L, Hemingway J, Ranson H. Elevated activity of an Epsilon class glutathione transferase confers DDT resistance in the dengue vector, Aedes aegypti. Insect Biochem Mol Biol 2005;35:861-71.

66. Riveron JM, Yunta C, Ibrahim SS, Djouaka R, Irving H, Menze BD, et al. A single mutation in the GSTe2 gene allows tracking of metabolically based insecticide resistance in a major malaria vector. Genome Biol 2014;15:R27.

67. Lumjuan N, Rajatileka S, Changsom D, Wicheer J, Leelapat P, Prapanthadara L, et al. The role of the Aedes aegypti Epsilon glutathione transferases in conferring resistance to DDT and pyrethroid insecticides. Insect Biochem Mol Biol 2011;41:203-9.

68. Werck-Reichhart D, Feyereisen R. Cytochromes P450: a success story. Genome Biol 2000;1. Reviews 3003.

69. Feyereisen R. In: Gilbert LI, Iatrou K, Gill SS, editors. Insect cytochrome P450. Oxford, UK: Elsevier; 2005. p. 1-77.

70. Despres L, David J-PP, Gallet C, Després L, David J-PP, Gallet C. The evolutionary ecology of insect resistance to plant chemicals. Trends Ecol Evol 2007;22:298-307.

71. Ffrench-Constant RH, Daborn PJ, Le Goff G. The genetics and genomics of insecticide resistance. Trends Genet 2004;20:163-70. 
72. Vontas J, Kioulos E, Pavlidi N, Morou E, della Torre A, Ranson H. Insecticide resistance in the major dengue vectors Aedes albopictus and Aedes aegypti. Pestic Biochem Physiol 2012;104:126-31.

73. Chiu T-L, Wen Z, Rupasinghe SG, Schuler MA. Comparative molecular modeling of Anopheles gambiae CYP6Z1, a mosquito P450 capable of metabolizing DDT. Proc Natl Acad Sci 2008;105:8855-60.

74. Mitchell SN, Stevenson BJ, Müller P, Wilding CS, Egyir-Yawson A, Field SG, et al. Identification and validation of a gene causing cross-resistance between insecticide classes in Anopheles gambiae from Ghana. Proc Natl Acad Sci USA 2012;109:6147-52.

75. Stevenson BJ, Bibby J, Pignatelli PM, Muangnoicharoen S, O’Neill PM, Liand L-Y, et al. Cytochrome P450 6M2 from the malaria vector Anopheles gambiae metabolizes pyrethroids: sequential metabolism of deltamethrin revealed. Insect Biochem Mol Biol 2011; 41:492-502.

76. Riveron JM, Irving H, Ndula M, Barnes KG, Ibrahim SS, Paine MJI, et al. Directionally selected cytochrome P450 alleles are driving the spread of pyrethroid resistance in the major malaria vector Anopheles funestus. Proc Natl Acad Sci 2013;110:252-7.

77. Chandor-Proust A, Bibby J, Régent-Kloeckner M, Roux J, Guittard-Crilat E, Poupardin R, et al. The central role of mosquito cytochrome P450 CYP6Zs in insecticide detoxification revealed by functional expression and structural modelling. Biochem J 2013;455:75-85.

78. Ibrahim SS, Riveron JM, Stott R, Irving H, Wondji CS. The cytochrome P450 CYP6P4 is responsible for the high pyrethroid resistance in knockdown resistance-free Anopheles arabiensis. Insect Biochem Mol Biol 2016;68:23-32.

79. Stevenson BJ, Pignatelli P, Nikou D, Paine MJI. Pinpointing P450s associated with pyrethroid metabolism in the dengue vector, Aedes aegypti: developing new tools to combat insecticide resistance. PLoS Negl Trop Dis 2012;6:e1595.

80. Riaz MA, Chandor-Proust A, Dauphin-Villemant C, Poupardin R, Jones CM, Strode C, et al. Molecular mechanisms associated with increased tolerance to the neonicotinoid insecticide imidacloprid in the dengue vector Aedes aegypti. Aquat Toxicol 2013;126: 326-37.

81. Kasai S, Komagata O, Itokawa K, Shono T, Ng LC, Kobayashi M, et al. Mechanisms of pyrethroid resistance in the dengue mosquito vector, Aedes aegypti: target site insensitivity, penetration, and metabolism. PLoS Negl Trop Dis 2014;8:e2948.

82. Hardstone MC, Scott JG. A review of the interactions between multiple insecticide resistance loci. Pestic Biochem Physiol 2010;97:123-8.

83. Edi CV, Djogbénou L, Jenkins AM, Regna K, Muskavitch MAT, Poupardin R, et al. CYP6 P450 enzymes and ACE-1 duplication produce extreme and multiple insecticide resistance in the malaria mosquito Anopheles gambiae. PLoS Genet 2014;10:e1004236.

84. Pasteur N, Georghiou GP, Iseki A. Variation in organophosphate resistance and esterase activity in Culex quinquefasciatus say from California. Génét Sél Evol 1984; 16:271-84.

85. Mouchès C, Magnin M, Bergé JB, de Silvestri M, Beyssat V, Pasteur N, et al. Overproduction of detoxifying esterases in organophosphate-resistant Culex mosquitoes and their presence in other insects. Proc Natl Acad Sci USA 1987;84:2113-6.

86. Georghiou GP, Pasteur N. Electrophoretic esterase patterns in insecticide-resistant and susceptible mosquitoes. J Econ Entomol 1978;71:201-5.

87. Mouchès C, Pasteur N, Bergé JB, Hyrien O, Raymond M, Robert de Saint Vincent B, et al. Amplification of an esterase gene is responsible for insecticide resistance in a California Culex mosquito. Science 1986;233:778-80. 
88. Vaughan A, Hawkes NJ, Hemingway J. Co-amplification explains linkage disequilibrium of two mosquito esterase genes in insecticide-resistant. Culex Quinquefasciatus Biochem J 1997;325:359-65.

89. Raymond M, Chevillon C, Guillemaud T, Lenormand T, Pasteur NA. An overview of the evolution of overproduced esterases in the mosquito Culex pipiens. Phil Trans $R$ Soc Lond B 1998;353:1707-11.

90. Guillemaud T, Raymond M, Tsagkarakou A, Bernard C, Rochard P, Pasteur N. Quantitative variation and selection of esterase gene amplification in Culex pipiens. Heredity 1999;83:87-99.

91. Weill M, Berticat C, Raymond M, Chevillon C. Quantitative polymerase chain reaction to estimate the number of amplified esterase genes in insecticide-resistant mosquitoes. Anal Biochem 2000;285:267-70.

92. Poupardin R, Srisukontarat W, Yunta C, Ranson H. Identification of carboxylesterase genes implicated in temephos resistance in the dengue vector Aedes aegypti. PLoS Negl Trop Dis 2014;8:e2743;

92a. Pocquet N, Darriet F, Zumbo B, Milesi P, Thiria J, Bernard V, et al. Insecticide resistance in disease vectors from Mayotte: an opportunity for integrated vector management. Parasit Vectors 2014;7:299. http://dx.doi.org/10.1186/1756-3305-7-299.

93. Grigoraki L, Lagnel J, Kioulos I, Kampouraki A, Morou E, Labbé P, et al. Transcriptome profiling and genetic study reveal amplified carboxylesterase genes implicated in temephos resistance, in the Asian tiger mosquito Aedes albopictus. PLoS Negl Trop Dis 2015;9: e0003771.

94. Somwang P, Yanola J, Suwan W, Walton C. Enzymes-based resistant mechanism in pyrethroid resistant and susceptible Aedes aegypti strains from northern Thailand. Parasitol Res 2011;109:531-7.

95. Fournier D, Bride JM, Mouchès C, Raymond M, Magnin M, Bergé JB, et al. Biochemical characterization of the esterases A1 and B1 associated with organophosphate resistance in the Culex pipiens complex. Pestic Biochem Physiol 1987; 27:211-7.

96. Cuany A, Handani J, Bergé JB, Fournier D, Raymond M, Georghiou GP, et al. Action of esterase B1 on chlorpyrifos in organophosphate-resistant Culex mosquitos. Pestic Biochem Physiol 1993;45:1-6.

97. Feyereisen R. Molecular biology of insecticide resistance. Toxicol Lett 1995;82:83-90.

98. Karunaratne SHPP, Hemingway J, Jayawardena KGI, Dassanayaka V, Vaughan A. Kinetic and molecular differences in the amplified and non-amplified esterases from insecticide-resistant and susceptible Culex quinquefasciatus mosquitoes. Biochem Biophys 1995;270:31124-8.

99. Claudianos C, Russell RJ, Oakeshott JG. The same amino acid substitution in orthologous esterases confers organophosphate resistance on the house fly and a blowfly. Insect Biochem Mol Biol 1999;29:675-86.

100. Pasteur N, Sinègre G, Gabinaud A. Est-2 and Est-3 polymorphism in Culex pipiens L. from southern France in relation to organophosphate resistance. Biochem Genet 1981;19: 499-508.

101. Raymond M, Berticat C, Weill M, Pasteur N, Chevillon C. Insecticide resistance in the mosquito Culex pipiens: what have we learned about adaptation? Genetica 2001;112-113: $1-10$.

102. Labbé P, Sidos N, Raymond M, Lenormand T. Resistance gene replacement in the mosquito Culex pipiens: fitness estimation from long term cline series. Genetics 2009;182: $303-12$. 
103. Chevillon C, Bourguet D, Rousset F, Pasteur N, Raymond M. Pleiotropy of adaptive changes in populations: comparisons among insecticide resistance genes in Culex pipiens. Genet Res 1997;70:195-204.

104. Lenormand T, Bourguet D, Guillemaud T, Raymond M. Tracking the evolution of insecticide resistance in the mosquito Culex pipiens. Nature 1999;400:861-4.

105. Berticat C, Boquien G, Raymond M, Chevillon C. Insecticide resistance genes induce a mating competition cost in Culex pipiens mosquitoes. Genet Res Camb 2002;79:41-7.

106. Berticat C, Duron O, Heyse D, Raymond M. Insecticide resistance genes confer a predation cost on mosquitoes, Culex pipiens. Genet Res 2004;83:189-96.

107. Bourguet D, Guillemaud T, Chevillon C, Raymond M. Fitness costs of insecticide resistance in natural breeding sites of the mosquito Culex pipiens. Evolution 2004;58: 128-35.

108. Duron O, Labbé P, Berticat C, Rousset F, Guillot S, Raymond M, et al. High Wolbachia density correlates with cost of infection for insecticide resistant Culex pipiens mosquitoes. Evolution 2006;60:303-14.

109. Ffrench-Constant RH, Anthony N, Aronstein K, Rocheleau T, Stilwell G, Richard H. Cyclodiene insecticide resistance: from molecular to population genetics. Annu Rev Entomol 2000;45:449-66.

110. McKenzie JA. Ecological and evolutionary aspects of insecticide resistance. Austin, Texas, USA: Academic Press; 1996.

111. Tantely ML, Tortosa P, Alout H, Berticat C, Berthomieu A, Rutee A, et al. Insecticide resistance in Culex pipiens quinquefasciatus and Aedes albopictus mosquitoes from La Reunion Island. Insect Biochem Mol Biol 2010;40:317-24.

112. Pocquet N, Milesi P, Makoundou P, Unal S, Zumbo B, Atyame C, et al. Multiple insecticide resistances in the disease vector Culex p. quinquefasciatus from Western Indian Ocean. PLoS One 2013;8:e77855.

113. Anthony N, Unruh T, Ganser D, Ffrench-Constant RH. Duplication of the Rdl GABA receptor subunit gene in an insecticide-resistant aphid, Myzus persicae. Mol Gen Genet 1998;260:165-75.

114. Remnant EJ, Good RT, Schmidt JM, Lumb C, Robin C, Daborn PJ, et al. Gene duplication in the major insecticide target site, Rdl, in Drosophila melanogaster. Proc Natl Acad Sci USA 2013;110:14705-10.

115. Lund AE. Pyrethroid modification of sodium channel: current concepts. Pestic Biochem Physiol 1984;22:161-8.

116. Vais H, Williamson MS, Devonshire AL, Usherwood PNR. The molecular interactions of pyrethroid insecticides with insect and mammalian sodium channels. Pest Manag Sci 2001;57:877-88.

117. Soderlund DM, Knipple DC. The molecular biology of knockdown resistance to pyrethroid insecticides. Insect Biochem Mol Biol 2003;33:563-77.

118. Dong K, Du Y, Rinkevich F, Nomura Y, Xu P, Wang L, et al. Molecular biology of insect sodium channels and pyrethroid resistance. Insect Biochem Mol Biol 2014;50: $1-17$.

119. Chandre F, Darriet F, Duchon S, Finot L, Richet IP, Manguin S, et al. Modifications of pyrethroid effects associated with kdr mutation in Anopheles gambiae. Med Vet Entomol 2000;14:81-8.

120. Williamson MS, Martinez-Torres D, Hick CA, Devonshire AL. Identification of mutations in the housefly para-type sodium channel gene associated with knockdown resistance $(\mathrm{kdr})$ to pyrethroid insecticides. Mol Gen Genet 1996;252:51-60. 
121. Martinez-Torres D, Chevillon C, Bergé JB, Pauron D, Brun-Barale A, Bergé JB, et al. Voltage-dependent $\mathrm{Na}^{+}$channels in pyrethroid-resistant Culex pipiens L. mosquitoes. Pestic Sci 1999;55:1012-20.

122. Etang J, Vicente JL, Nwane P, Chouaibou M, Morlais I, Do Rosario VE, et al. Polymorphism of intron-1 in the voltage-gated sodium channel gene of Anopheles gambiae s.s. populations from Cameroon with emphasis on insecticide knockdown resistance mutations. Mol Ecol 2009;18:3076-86.

123. Chandre F, Darriet F, Manguin S, Brengues C, Carnevale P, Guillet P. Pyrethroid cross resistance spectrum among populations of Anopheles gambiae s.s. from Cote d'ivoire. J Am Mosq Control Assoc 1999;15:53-9.

124. Ranson H, Jensen B, Vulule JM, Wang X, Hemingway J, Collins FH. Identification of a point mutation in the voltage-gated sodium channel gene of Kenyan Anopheles gambiae associated with resistance to DDT and pyrethroids. Insect Mol Biol 2000; 9:491-7.

125. Brengues C, Hawkes NJ, Chandre F, Mccarroll L, Duchon S, Guillet P, et al. Pyrethroid and DDT cross-resistance in Aedes aegypti is correlated with novel mutations in the voltage-gated sodium channel gene. Med Vet Entomol 2003;17:87-94.

126. Du Y, Nomura Y, Satar G, Hu Z, Nauen R, Yang S, et al. Molecular evidence for dual pyrethroid-receptor sites on a mosquito sodium channel. Proc Natl Acad Sci USA 2013; 110:11785-90.

127. Brooke BD. kdr: can a single mutation produce an entire insecticide resistance phenotype? Trans $R$ Soc Trop Med Hyg 2008;102:524-5.

128. Xu Q, Wang H, Zhang L, Liu N. Kdr allelic variation in pyrethroid resistant mosquitoes, Culex quinquefasciatus (S.). Biochem Biophys Res Commun 2006;345:774-80.

129. Awolola TS, Oduola AO, Oyewole IO, Obansa JB, Amajoh CN, Koekemoer LL, et al. Dynamics of knockdown pyrethroid insecticide resistance alleles in a field population of Anopheles gambiae s.s. in southwestern Nigeria. J Vector Borne Dis 2007;44:181-8.

130. Reimer L, Fondjo E, Patchoké S, Diallo B, Lee Y, Ng A, et al. Relationship between kdr mutation and resistance to pyrethroid and DDT insecticides in natural populations of Anopheles gambiae. J Med Entomol 2008;45:260-6.

131. Dabiré RK, Diabaté A, Namontougou M, Toé KH, Ouari A, Kengne P, et al. Distribution of pyrethroid and DDT resistance and the L1014F kdr mutation in Anopheles gambiae s.l. from Burkina Faso (West Africa). Trans R Soc Trop Med Hyg 2009;103:1113-20.

132. Ramphul U, Boase T, Bass C, Okedi LM, Donnelly MJ, Muller P. Insecticide resistance and its association with target-site mutations in natural populations of Anopheles gambiae from eastern Uganda. Trans R Soc Trop Med Hyg 2009;103:1121-6.

133. Stump AD, Atieli FK, Vulule JM, Besansky NJ. Dynamics of the pyrethroid knockdown resistance allele in Western Kenyan populations of Anopheles gambiae in response to insecticide-treated bed net trials. Am J Trop Med Hyg 2004;70:591-6.

134. Lynd A, Weetman D, Barbosa S, Egyir Yawson A, Mitchell SN, Pinto J, et al. Field, genetic and modelling approaches show strong positive selection acting upon an insecticide resistance mutation in Anopheles gambiae s.s. Mol Biol Evol 2010;27:1117-25.

135. Norris LC, Main BJ, Lee Y, Collier TC, Fofana A, Cornel AJ, et al. Adaptive introgression in an African malaria mosquito coincident with the increased usage of insecticide-treated bed nets. Proc Natl Acad Sci 2015;112:201418892.

136. Weill M, Chandre F, Brengues C, Manguin S, Akogbéto MC, Pasteur N, et al. The kdr mutation occurs in the Mopti form of Anopheles gambiae s.s. through introgression. Insect Mol Biol 2000;9:451-5. 
137. Pinto J, Lynd A, Vicente JL, Santolamazza F, Randle NP, Gentile G, et al. Multiple origins of knockdown resistance mutations in the Afrotropical mosquito vector Anopheles gambiae. PLoS One 2007;2:e1243.

138. N'Guessan R, Corbel V, Akogbéto MC, Rowland MW. Reduced efficacy of insecticidetreated nets and indoor residual spraying for malaria control in pyrethroid resistance area, Benin. Emerg Infect Dis 2007;13:199-206.

139. Casimiro SLR, Hemingway J, Sharp BL, Coleman M. Monitoring the operational impact of insecticide usage for malaria control on Anopheles funestus from Mozambique. Malar J 2007;6:142.

140. Enayati AA, Hemingway J. Pyrethroid insecticide resistance and treated bednets efficacy in malaria control. Pestic Biochem Physiol 2006;84:116-26.

141. Weill M, Fort P, Berthomieu A, Dubois MP, Pasteur N, Raymond M. A novel acetylcholinesterase gene in mosquitoes codes for the insecticide target and is non-homologous to the ace gene in Drosophila. Proc Biol Sci 2002;269:2007-16.

142. Huchard E, Martinez M, Alout H, Douzery EJP, Lutfalla G, Berthomieu A, et al. Acetylcholinesterase genes within the Diptera: takeover and loss in true flies. Proc Biol Sci 2006;273:2595-604.

143. Fournier D, Mutéro A. Modification of acetylcholinesterase as a mechanism of resistance to insecticides. Comp Biochem Physiol 1994;108C:19-31.

144. Weill M, Lutfalla G, Mogensen K, Chandre F, Berthomieu A, Berticat C, et al. Insecticide resistance in mosquito vectors. Nature 2003;423:423-6.

145. Labbé P, Berthomieu A, Berticat $\mathrm{C}$, Alout H, Raymond M, Lenormand $\mathrm{T}$, et al. Independent duplications of the acetylcholinesterase gene conferring insecticide resistance in the mosquito Culex pipiens. Mol Biol Evol 2007;24:1056-67.

146. Nabeshima T, Mori A, Kozaki T, Iwata Y, Hidoh O, Harada S, et al. An amino acid substitution attributable to insecticide-insensitivity of acetylcholinesterase in a Japanese encephalitis vector mosquito, Culex tritaeniorhynchus. Biochem Biophys Res Commun 2004;313:794-801.

147. Alout H, Berthomieu A, Berticat C. Different amino-acid substitutions confer insecticide resistance through acetylcholinesterase 1 insensitivity in Culex vishnui and Culex tritaeniorhynchus (Diptera: Culicidae) mosquitoes from China. J Med Entomol 2007;44:463-9.

148. Alout H, Berthomieu A, Hadjivassilis A, Weill M. A new amino-acid substitution in acetylcholinesterase 1 confers insecticide resistance to Culex pipiens mosquitoes from Cyprus. Insect Biochem Mol Biol 2007;37:41-7.

149. Alout H, Labbé P, Berthomieu A, Pasteur N, Weill M. Multiple duplications of the rare ace-1 mutation F290V in Culex pipiens natural populations. Insect Biochem Mol Biol 2009;39:884-91.

150. Alout H, Djogbénou L, Berticat C, Chandre F, Weill M. Comparison of Anopheles gambiae and Culex pipiens acetycholinesterase 1 biochemical properties. Comp Biochem Physiol B Biochem Mol Biol 2008;150:271-7.

151. Alout H, Labbé P, Berthomieu A, Makoundou P, Fort P, Pasteur N, et al. High chlorpyrifos resistance in Culex pipiens mosquitoes: strong synergy between resistance genes. Heredity 2015;116:224-31.

152. Assogba BS, Djogbénou LS, Saizonou J, Milesi P, Djossou L, Djegbe I, et al. Phenotypic effects of concomitant insensitive acetylcholinesterase $\left(\right.$ ace $\left.-1^{R}\right)$ and knockdown resistance $\left(k d r^{R}\right)$ in Anopheles gambiae: a hindrance for insecticide resistance management for malaria vector control. Parasit Vectors 2014;7:548. 
153. Raymond M, Fournier D, Bride JM, Cuany A, Bergé JB, Magnin M, et al. Identification of resistance mechanisms in Culex pipiens (Diptera: Culicidae) from southern France: insensitive acetylcholinesterase and detoxifying oxidases. J Econ Entomol 1986;79: 1452-8.

154. Bourguet D, Roig A, Toutant JP, Arpagaus M. Analysis of molecular forms and pharmacological properties of acetylcholinesterase in several mosquito species. Neurochem Int 1997;31:65-72.

155. Lenormand T, Guillemaud T, Bourguet D, Raymond M. Appearance and sweep of a gene duplication: adaptive response and potential for new functions in the mosquito Culex pipiens. Evolution 1998;52:1705-12.

156. Labbé P, Milesi P, Yébakima A, Pasteur N, Weill M, Lenormand T. Gene-dosage effects on fitness in recent adaptive duplications: ace-1 in the mosquito Culex pipiens. Evolution 2014;68:2092-101.

157. Labbé P, Berticat C, Berthomieu A, Unal S, Bernard C, Weill M, et al. Forty years of erratic insecticide resistance evolution in the mosquito Culex pipiens. PLoS Genet 2007;3: e205.

158. Djogbénou L, Chandre F, Berthomieu A, Dabiré RK, Koffi A, Alout H, et al. Evidence of introgression of the ace-1R mutation and of the ace-1 duplication in west African Anopheles gambiae s.s. PLoS One 2008;3:e2172. 1-7.

159. Dabiré KR, Diabaté A, Namontougou M, Djogbenou L, Kengne P, Simard F, et al. Distribution of insensitive acetylcholinesterase $\left(\right.$ ace- $\left.1^{R}\right)$ in Anopheles gambiae s.l. populations from Burkina Faso (West Africa). Trop Med Int Heal 2009;14:396-403.

160. Assogba BS, Djogbénou LS, Milesi P, Berthomieu A, Perez J, Ayala D, et al. An ace-1 gene duplication resorbs the fitness cost associated with resistance in Anopheles gambiae, the main malaria mosquito. Sci Rep 2015;5:14529.

161. Djogbénou L, Labbé P, Chandre F, Pasteur N, Weill M. Ace-I duplication in Anopheles gambiae: a challenge for malaria control. Malar J 2009;8:70.

162. Weetman D, Mitchell SN, Wilding CS, Birks DP, Yawson AE, Essandoh J, et al. Contemporary evolution of resistance at the major insecticide target site gene Ace-1 by mutation and copy number variation in the malaria mosquito Anopheles gambiae. Mol Ecol 2015;24:265-72.

163. Djogbénou LS, Assogba B, Essandoh J, Constant EAV, Makoutodé M, Akogbéto M, et al. Estimation of allele-specific Ace-1 duplication in insecticide-resistant Anopheles mosquitoes from West Africa. Malar J 2015;14:507.

164. Després L, Stalinski R, Tetreau G, Paris M, Bonin A, Navratil V, et al. Gene expression patterns and sequence polymorphisms associated with mosquito resistance to Bacillus thuringiensis israelensis toxins. BMC Genomics 2014;15:926.

165. Tetreau G, Alessi M, Veyrenc S, David J, Reynaud S. Fate of Bacillus thuringiensis subsp. israelensis in the field : evidence for spore recycling and differential persistence of toxins in leaf litters. Appl Environ Microbiol 2012;78:8362.

166. Nielsen-Leroux C, Pasteur N, Prètre J, Charles J, Sheikh HB, Chevillon C. High resistance to Bacillus sphaericus binary toxin in Culex pipiens (Diptera: Culicidae): the complex situation of west Mediterranean countries. J Med Entomol 2002;39:729-35.

167. Chevillon C, Bernard C, Marquine M, Pasteur N. Resistance to Bacillus sphaericus in Culex pipiens (Diptera: Culicidae): interaction between recessive mutants and evolution in southern France. J Med Entomol 2001;38:657-64.

168. Nielsen-Leroux C, Charles JF, Georghiou GP. Resistance in a laboratory population of Culex quinquefasciatus (Diptera: Culicidae) to Bacillus sphaericus binary toxin is due to a 
change in the receptor on midgut brush-border membranes. Eur J Biochem 1995;228: 206-10.

169. Darboux I, Pauchet Y, Castella C, Silva-Filha MH, Nielsen-LeRoux C, Charles J-F, et al. Loss of the membrane anchor of the target receptor is a mechanism of bioinsecticide resistance. Proc Natl Acad Sci USA 2002;99:5830-5.

170. Darboux I, Charles JF, Pauchet Y, Pauron D. Transposon-mediated resistance to Bacillus sphaericus in a field-evolved population of Culex pipiens (Diptera: Culicidae). Cell Microbiol 2007;9:2022-9.

171. Saavedra-Rodríguez K, Urdaneta-Marquez L, Rajatileka S, Moulton M, Flores AE, Fernández-Salas I, et al. A mutation in the voltage-gated sodium channel gene associated with pyrethroid resistance in Latin American Aedes aegypti. Insect Mol Biol 2007;16: 785-98.

172. García GP, Flores AE, Fernández-Salas I, Saavedra-Rodríguez K, Reyes-Solis G, LozanoFuentes $\mathrm{S}$, et al. Recent rapid rise of a permethrin knock down resistance allele in Aedes aegypti in Mexico. PLoS Negl Trop Dis 2009;3:e531.

173. Kawada H, Higa Y, Nguyen YT, Tran SH, Nguyen HT, Takagi M. Nationwide investigation of the pyrethroid susceptibility of mosquito larvae collected from used tires in Vietnam. PLoS Negl Trop Dis 2009;3:e391.

174. Marcombe S, Poupardin R, Darriet F, Reynaud S, Bonnet J, Strode C, et al. Exploring the molecular basis of insecticide resistance in the dengue vector Aedes aegypti: a case study in Martinique Island (French West Indies). BMC Genomics 2009;10:494.

175. Brogdon WG, McAllister JC. Insecticide resistance and vector control. Emerg Infect Dis 1998;4:605-13.

176. Raymond M, Heckel DG, Scott JG. Interactions between pesticide genes. Model and experiment. Genetics 1989;123:543-51.

177. Bonnet J, Pennetier C, Duchon S, Lapied B, Corbel V. Multi-function oxidases are responsible for the synergistic interactions occurring between repellents and insecticides in mosquitoes. Parasit Vectors 2009;2:17.

178. Berticat C, Bonnet J, Duchon S, Agnew P, Weill M, Corbel V. Costs and benefits of multiple resistance to insecticides for Culex quinquefasciatus mosquitoes. BMC Evol Biol $2008 ; 8$

179. Vontas JG, McCarroll L, Karunaratne SHPP, Louis C, Hurd H, Hemingway J. Does environmental stress affect insect-vectored parasite transmission? Physiol Entomol 2004; 29:210-3.

180. Rivero A, Vézilier J, Weill MM, Read AF, Gandon S. Insecticide control of vector-borne diseases: when is insecticide resistance a problem? PLoS Pathog 2010;6:e1001000.

181. Alout H, Ndam NT, Sandeu MM, Djégbe I, Chandre F, Dabiré RK, et al. Insecticide resistance alleles affect vector competence of Anopheles gambiae s.s. for Plasmodium falciparum field isolates. PLoS One 2013;8:e63849.

182. Alout H, Djègbè I, Chandre F, Djogbénou LS, Dabiré RK, Corbel V, et al. Insecticide exposure impacts vector-parasite interactions in insecticide-resistant malaria vectors. Proc $R$ Soc B 2014;281:20140389.

183. Kelly-Hope LA, Ranson H, Hemingway J. Lessons from the past: managing insecticide resistance in malaria control and eradication programmes. Lancet Infect Dis 2008;8: $387-9$. 